\title{
Ontologia piękna i wzniosłości w architekturze. Inspiracje Heideggerowskie
}

\author{
Henryk Benisz \\ https://orcid.org/0000-0001-5449-0760
}

\begin{abstract}
Zgodnie z greckim ujęciem sztuki jako techne, architektura jest sztuką konstrukcyjną podlegającą ustalonym regułom tworzenia. Idea piękna przekracza jednak sztywne ramy kanonu, gdyż kalón ma nie tylko estetyczny, ale także etyczny i religijny charakter. Obiekty sakralne są otwarte na świat i innych ludzi (wymiar horyzontalny) oraz na zaświaty i bogów lub Boga (wymiar wertykalny). Ku prawdzie piękna prowadzi nas ontologia fundamentalna Heideggera, która odnawia związki między Ziemią i Niebem, Istotami Boskimi i Śmiertelnymi. Uczy ona, że budowanie, mieszkanie i myślenie są źródłowo tożsame. Podczas projektowania należy nie tylko zachowywać miarę i proporcje, aby sprostać potrzebie piękna i użyteczności, ale też uwzględniać owe związki. W ten sposób strzeże się domu bycia i domostwa istoty człowieka.
\end{abstract}

Słowa kluczowe: architektura, piękno, wzniosłość, kanon, ontologia, Heidegger

\section{Wprowadzenie do architektury jako sztuki budowania}

Architektura jest specyficzną sztuką, pełniącą wiele istotnych ról. W artykule tym chciałbym pokazać, że jest ona nie tylko sztuką wznoszenia pięknych obiektów budowlanych, ale jest również sztuką budowania wzniosłych relacji między ludźmi i bogami, a nawet z pozoru prostymi rzeczami tego świata. Architektura

HENRYK BENISZ, prof. dr hab., Wydział Nauk Społecznych, Uniwersytet Opolski; adres do korespondencji: Wydział Nauk Społecznych Uniwersytetu Opolskiego, ul. Oleska 48, 45-052 Opole; e-mail: benisz@uni.opole.pl 
kreuje więc świat jako taki i umożliwia źródłową komunikację między wszystkimi jego kluczowymi elementami. Wielką pomocą w takim pojmowaniu architektury jest dla mnie Martin Heidegger, który w swej twórczości z równą stanowczością opowiada się za rozstrzygnięciami ustalonymi w greckiej starożytności i za ustaleniami rozstrzygającymi się w naszej aktualnej współczesności. Z patosem powagi można by zaryzykować twierdzenie, że sprawy tutaj poruszane mają walor ponadczasowości czy wieczności, zarazem nie tracąc swego ważnego rysu antropologicznego czy humanistycznego.

\section{Filozoficzna (prze)mowa o architekturze}

W starożytności, chcąc uchodzić za artystę, trzeba się było wykazać przyrodzonymi zdolnościami (natura), wiedzą (doctrina) i doświadczeniem (usus). Ta trychotomia profesjonalizmu była szczególnie pożądana u architektów, których sztuka wymagała przestrzegania ściśle określonego kanonu. Główne zasady sztuki budowania zostały zebrane we wzorcowym podręczniku zatytułowanym De architectura Libri X, którego autorem jest rzymski architekt Marcus Vitruvius Pollio. Wydaje się, że spośród wielu specyficznych właściwości architektury, jakie zostały tam scharakteryzowane, na pierwszy plan wysuwają się eurytmia (eurythmia) i symetria (symmetria). Witruwiusz pisze, że eurytmia "polega na pełnym wdzięku wyglądzie budowli i na właściwym zestawieniu poszczególnych członów”, natomiast symetria ,jest harmonijną zgodnością wynikającą z członów samego dzieła i współzależnością między określonymi członami poszczególnych części a całością dzieła"1. W nawiązaniu do przedstawionej przez Witruwiusza teorii budowania Tatarkiewicz kreśli obszar kompetencji dawnego architekta:

Powinien znać się nie tylko na sprawach ściśle budowlanych, ale także na arytmetyce, optyce, historii (potrzebnej dla zrozumienia form architektonicznych), medycynie (aby budynki były higieniczne), prawie, muzyce (aby budynki były akustyczne), astronomii, geografii (aby odpowiednio ustawić budynek lub doprowadzić

${ }^{1}$ Witruwiusz, $O$ architekturze ksiąg dziesięć, tłum. Kazimierz Kumaniecki (Warszawa: PWN, 1956), 15 (ks. I, rozdz. 2, 3-4). 
doń wodę). Co więcej, powinien być wykształcony filozoficznie, a to dlatego, że musi być człowiekiem $\mathrm{z}$ charakterem, a ten wyrabia filozofia ${ }^{2}$.

Nie ma się co dziwić, że obiekty wznoszone przez takich budowniczych charakteryzowały się trwałością (firmitas), użytecznością (utilitas) i pięknem (venustas). Można dodać, że trwałość i użyteczność potwierdzały, czy też utwierdzały piękno budowli, a w jakimś sensie były również aspektem owego piękna.

Zwykle mówi się, że dla Greków sztuka to techne, czyli swoiste rzemiosło lub umiejętność tworzenia zgodnie z ustalonymi regułami, jednakże dla Heideggera zakres znaczeniowy tego pojęcia jest znacznie szerszy. Pierwotnie techne oznaczała wydobywanie i uobecniane. Zgodnie $z$ tą wykładnią techne, „pozwala ona ujawnić się czemuś - tak, że wprowadza wydobyte, jako obecne, w to, co już obecne"3. Mimo że sama wydobywa, ją też trzeba wydobyć, aby rozpoznać właściwy charakter dzieła sztuki. Pewnie jest tak dlatego, że już o niej zapomnieliśmy, podobnie jak przedtem zapomnieliśmy o byciu bytu. W rezultacie, patrząc na przykład na piękną budowlę, nie dostrzegamy jej „technicznego” komponentu: „Tak pomyślana techne ukrywa się z dawien dawna w tektonicznym elemencie architektury"4. Przed naszymi oczyma często skrywa się też idea fundująca powstanie dzieła sztuki, a zarazem określająca jego teleologię. Gdy na przykład patrzymy na starożytną świątynię, to zwykle podziwiamy tylko jej walory estetyczne, czyli zewnętrzne piękno, i nie zwracamy uwagi na jej źródłowe piękno, czyli piękno wewnętrzne, o którym stanowią bogowie owej świątyni. W tym kontekście zauważmy, że Grecy przedstawiali swych bogów w postaci ludzi, ale przedstawienia te, niewątpliwie mające piękną formę, jedynie symbolizowały bogów, którzy przecież formę tę przyjmowali wyłącznie ze względu na ludzi - aby mogli być przez nich (roz)poznani. Pojęcie pięknej formy okazuje się problematyczne, gdy głębiej zastanawiamy się nad znaczeniem takich pojęć, jak wspomniana już eurytmia i symetria. Właściwie cała sfera piękna jest dość enigmatyczna, podobnie jak sfera bogów w sobie, do której nie mamy bezpośredniego dostępu. Idąc dalej tym tropem, możemy dojść do wniosku, że piękno (kalón) jest pierwotnie cechą boską.

${ }^{2}$ Władysław Tatarkiewicz, Historia estetyki, t. 1: Estetyka starożytna (Wrocław-Kraków: Zakład Narodowy imienia Ossolińskich, 1960), 316.

${ }^{3}$ Martin Heidegger, „Budować, mieszkać, myśleć”, w: tenże, Budować, mieszkać, myśleć, tłum. Krzysztof Michalski (Warszawa: Czytelnik, 1977), 332.

${ }^{4}$ Tamże. 
Ku takiemu myśleniu skłania zwłaszcza Platon, snujący w jednym z najbardziej znanych dialogów swą opowieść o Erosie, bogu miłości albo symbolu miłości do piękna lub pięknej miłości - opowieść rozpisaną na role i finezyjnie przedstawioną przez zgromadzonych w domu Agatona uczestników słynnego sympozjonu. Eros jest tu reprezentantem sfery „między”, łączącym ludzi i bogów, a właściwie pozwalającym wznosić się ludzkiej miłości z nizin cielesnych fascynacji ku wyżynom boskiego piękna w czystej, duchowej postaci. Pouczająca Sokratesa Diotyma z Mantinei bardzo sugestywnie mówi:

\begin{abstract}
Na tym szczeblu dopiero życie jest coś warte: wtedy, gdy człowiek piękno samo w sobie ogląda [...]. Gdyby komu było dane zobaczyć piękno samo w sobie, nieskalane, czyste, wolne od obcych pierwiastków, nie splamione ludzkimi namiętnościami i barwami, i wszelką lichotą śmiertelną, ale to nadświatowe, wieczne, jedyne, niezmienne piękno samo w sobie. Co myślisz, czy by mógł jeszcze wtedy marne życie pędzić człowiek, który aż tam patrzy i to widzi, i z tym obcuje? ${ }^{5}$
\end{abstract}

Wydaje się, że nie mógłby. Również architekt nie mógłby projektować marnych budowli, nie dosięgających wyżyn czystego budowania. Utwierdzamy się tutaj w przekonaniu, że świątynia jest piękna głównie wtedy, gdy dobrze oddaje naturę zamieszkujących ją bogów, a dopiero wtórnie dzięki temu, że została ładnie wybudowana i ozdobiona. Wznosząc świątynię, trzeba zatem wznosić ją ku bogom, tak by była materialnym symbolem duchowej wzniosłości.

Kategoria wzniosłości stała się jednym z filarów nowożytnej estetyki dzięki Kantowi. Filozof ten, słynący z gruntownych analiz sądu smaku (Geschmacksurtei), sądu wprawdzie subiektywnego, ale pretendującego do powszechności i konieczności oraz warunkującego odczuwanie estetycznej rozkoszy, zwrócił uwagę również na to, co wzniosłe, czyli - napiszmy to w wyraźny sposób - na Wzniosłe (das Erhabene) jako na „to, co jest absolutnie wielkie [...], co jest ponad wszelkie porównanie wielkie" i dlatego wzbudza szacunek ${ }^{7}$ oraz wywołuje wzruszenie ${ }^{8}$. Wprawdzie dla Kanta wzniosłość jest w zasadzie cechą wyższego sposobu myśle-

${ }^{5}$ Platon, „Uczta”, w: tenże, Uczta. Eutyfron. Obrona Sokratesa. Kriton. Fedon, tłum. Władysław Witwicki (Warszawa: PWN, 1982), 115-116 (211 D-E).

${ }^{6}$ Immanuel Kant, Krytyka władzy sądzenia, tłum. Jerzy Gałecki (Warszawa: PWN, 2004), 136.

${ }^{7}$ Tamże, 139, 175.

${ }^{8}$ Tamże, 100, 131, 142. 
nia i dotyczy przede wszystkim jakości abstrakcyjnych (np. formuł matematycznych), a więc jakoś zawiera się w człowieku zdolnym do takiego myślenia, jednak wiąże on to pojęcie także z jakąś potęgą, również z boską potęgą, $\mathrm{w}$ reakcji na którą następuje „padanie na ziemię, okazywanie czci pochyloną głową, wśród gestów i wykrzykiwań pełnych skruchy i lęku" . W tym ujęciu wzniosłość jest już bliska uczuciu architekta, który wznosi świątynię, i uczuciu wiernego, który w tej świątyni modli się do bogów lub Boga. Kant stwierdza, że wzniosłość, tak samo jak piękno, „podoba się sama dla siebie” 10 , lecz w odróżnieniu od piękna, które w przyrodzie zawsze ma jakąś formę, wzniosłość może być pozbawiona formy ${ }^{11}$. Wynika stąd, iż wzniosłość pierwotnie powstaje w innym wymiarze, gdzieś poza czy ponad przyrodą, czyli w wymiarze nadprzyrodzonym (transcendentnym), i w jeszcze większym stopniu niż piękno jest zależna od bogów.

Niejako absolutnym dopełnieniem starożytnej architektury greckiej i rzymskiej stała się średniowieczna architektura chrześcijańska, w której do głosu doszła wszechobecna wówczas idea Boga. W tej teocentrycznej epoce obiekty religijne oraz budowle o szczególnie ważnym znaczeniu miały symbolizować Boga i jego dzieło stworzenia. Charakterystyczne w tym względzie są świątynie z trzema jednakowymi fasadami i trzema oknami, przez które światło wnika do wnętrza i oświetla chór. Ten obraz boskiej iluminacji, unaoczniający główne rysy filozofii św. Augustyna, ma też, dziwnym trafem, wymowę pogańską wskutek wyeksponowania chóru, który odgrywał kluczową rolę w religii dionizyjskiej i w towarzyszącej jej tragedii attyckiej. Nietzsche przypomina, „że tragedia powstała $z$ tragicznego chóru i że pierwotnie była tylko chórem i niczym więcej"12. Tak oto w klimacie poniekąd uniwersalnej sakralności ludzie tamtego czasu doświadczali swego konstytutywnego związku z absolutem. Można powiedzieć, że na ich oczach uobecniały się zaślubiny sfery ziemskiej z niebiańską. Tę samą ideę jedności wszechrzeczy dostrzegamy w prostej architektonicznej koncepcji świątyni jako sześcianu z nałożoną u góry półkulą. Ziemia jest tu, co oczywiste, podporządkowana niebu. Czworoboczna konstrukcja obiektu pokazuje, że w wymiarze horyzontalnym jesteśmy otwarci na cztery strony świata, które zarazem jednak wyznaczają granice

\footnotetext{
${ }^{9}$ Tamże, 161.

${ }^{10}$ Tamże, 130.

${ }^{11}$ Tamże, 131.

${ }^{12}$ Friedrich Nietzsche, Narodziny tragedii albo Grecy i pesymizm, tłum. Bogdan Baran (Kraków: Wydawnictwo Baran i Suszczyński, 2001), 63.
} 
naszego ziemskiego bytu. Prawdziwa, tj. bezgraniczna otwartość ujawnia się dopiero w wymiarze wertykalnym, który pozwala nam wznosić się ku niebiosom, a przynajmniej ku kosmosowi symbolizującemu boski porządek wszechrzeczy. Te proste formy zostały zastosowane najpierw przy wznoszeniu grobowców, potem mauzoleów, a w końcu świątyń ${ }^{13}$ i właśnie w tych ostatnich prosta forma zawarła w sobie pełnię treści o wszystkim, co istnieje. Zastanawiające jest to, że właśnie owa prosta, ascetyczna forma jest tak bogata $\mathrm{w}$ treść. O ile bowiem na Wschodzie lubowano się w bizantyjskim przepychu i swoistą „różnicę ontologiczną” między bytem ludzkim a byciem bogów usiłowano zniwelować pięknymi ikonami, przenoszącymi nas od tego, co symbolizowane, do tego, co przedstawiane (wyobrażane), o tyle na Zachodzie trzymano się prostych form artystycznych, być może zdając sobie sprawę z tego, że piękno, dobro i prawda nie potrzebują przepychu, aby się objawić człowiekowi. Wspomniany św. Augustyn, mimo swej prostej i wręcz surowej religijności, zachwycał się pięknem świata jako boskiego, rozumnego tworu i napisał, że „podoba mu się [rozumowi - H.B.] tylko piękno, w pięk-

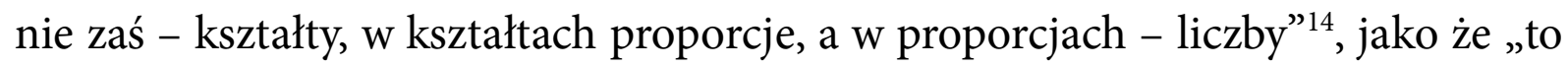
tylko ma związek z rozumem, co odznacza się pewną miarą i proporcją" ${ }^{\prime 5}$. Św. Augustyn dodaje: „Stąd też architekci mówią w swoim języku, że elementy harmonijnie rozmieszczone są rozmieszczone rozumowo, natomiast rozmieszczone nieharmonijnie - nierozumowo"16. Jego zdaniem przy zmartwychwstaniu Bóg przywróci każdemu człowiekowi jego pierwotne piękno, „tak, aby kształtny stosunek członków był zachowany” lub też tak, „żeby całość materii zachowana została, a niekształtność wszystka usunięta” ${ }^{17}$. I znowu na pociechę dodaje: „Nie mają się tedy czego obawiać ani chuderlacy, ani tłuściochy”"18. Nie inaczej jest w filozofii św. Tomasza, który niemal z lubością kontemplował piękno świata i poprzez nie docho-

${ }^{13}$ Władysław Tatarkiewicz, Historia estetyki, t. 2: Estetyka średniowieczna (Wrocław-Kraków: Zakład Narodowy imienia Ossolińskich, 1960), 40.

${ }^{14}$ Św. Augustyn, „O porządku”, tłum. Józef Modrzejewski, w: tenże, Dialogi filozoficzne(Kraków: Znak, 2001), 222 (ks. II, rozdz. 42).

${ }^{15}$ Tamże, 216 (ks. II, rozdz. 33).

${ }^{16}$ Tamże, 216 (ks. II, rozdz. 34).

${ }^{17}$ Św. Augustyn, Państwo Boże, tłum. Władysław Kubicki (Kęty: Wydawnictwo Antyk, 2002), 939 (ks. XXII, rozdz. 19).

${ }^{18}$ Tamże, 940 (ks. XXII, rozdz. 19). 
dził do piękna Boga jako Stwórcy. Również on uważał, że „piękno polega na należytej proporcji” ${ }^{19}$ oraz na pewnym blasku, który zapewne bierze się z obecności Boga w świecie, czyli zasadza się na boskiej immanencji. Oba przekonania jako żywo wpisują się w Witruwiańskie rozumienie piękna, co może niezmiernie dziwić, ponieważ poglądy św. Augustyna i św. Tomasza pod innymi względami bardzo się od siebie różnią. Zasadniczo dzieli ich nie tylko spory dystans czasowy (pierwszy reprezentuje patrystykę, natomiast drugi - scholastykę), ale też inne źródło inspiracji (u pierwszego jest nim filozofia Platona, u drugiego - Arystotelesa). W tym, co piękne i dlaczego piękne nie ma jednak między nimi rozdźwięku. Ich mowa na ten temat jest tak samo rytmiczna i harmonijna. A może nie jest to już mowa, tylko śpiew?...

\section{Śpiewne dopełnienie (prze)mowy o architekturze}

Śpiew towarzyszy sztuce od początku jej istnienia, przy czym doskonale łączy się on ze sztuką słowa. Chór greckiej tragedii czy późniejsza twórczość trubadurów najlepiej o tym świadczą. Dla Heideggera, który usiłował wnikać w ukrytą treść poezji Rainera Marii Rilkego, prawdziwy śpiew, czy też śpiew ujawniający prawdę bycia, zaczyna się tam, gdzie milkną słowa, ponieważ nie potrafią już wyrazić niewyrażalnego. Poeci żyjący w czasie marnym, błąkający się po bezdrożach spowitych Nocą Świata i szukający śladów zbiegłych bogów, ostatecznie skazani są na porzucenie przekazu werbalnego. Przestają mówić, ale nie przestają trwać w przestrzeni wypełnionej niewymowną wzniosłością: „Poeci z rodzaju tych, którzy bardziej ryzykują, są w drodze, na tropie świętości, gdyż doświadczają rozpaczliwości jako takiej. Ich pieśń nad ziemią - uświęca. Ich śpiew święci nienaruszoność kuli bycia"20. W ten sposób poezja w zadziwiający sposób upodabnia się do architektury, chociaż ta nie musiała zamilknąć, ponieważ od początku nastawiona jest na milczenie. Nie aspirując do bycia sztuką ekspresyjną, służy jedynie potęgowaniu przekazu słowno-muzycznego, gdy nadarza się taka okazja. Trudno jednak wskazać lepsze miejsce do kultywowania pięknego i specyficznie wymownego śpiewu

${ }^{19}$ Św. Tomasz, Suma teologiczna, t. 1: O Bogu, tłum. o. Pius Bełch OP (Londyn: Katolicki Ośrodek Wydawniczy „Veritas”, 1975), 74 (zag. 5, art. 4).

${ }^{20}$ Martin Heidegger, „Cóż po poecie?”, tłum Krzysztof Wolicki, w: tenże, Drogi lasu (Warszawa: Fundacja Aletheia, 1997), 258. 
niż dobrze zaprojektowane obiekty architektoniczne. Stoją one majestatycznie we właściwej dla siebie przestrzeni i pozwalają ulatywać dźwiękom w nieznane - tam, gdzie pieśń odnajduje dla siebie wieczne spełnienie. Ta przepiękna celebracja celu istnienia wszystkiego, co było, jest i będzie, oznacza zarazem uświęcenie prapoczątku wszechrzeczy. Tam bowiem, gdzie wszystko się kończy, tam też wszystko kiedyś się zaczęło, a może wiecznie zaczyna się od nowa. Nie wiemy na pewno, czy czas zawłaszczający przestrzeń biegnie po linii prostej, czy po kole. Architektura skutecznie rozprawia się z tą ontologiczną niewiedzą, trwale wiążąc elementy ufundowane na bazie linii prostych i przecinających się płaszczyzn z elementami o formach kulistych. To, co ma swe zakończenie i jakby z natury rzeczy jest zamknięte, uzupełniane jest tym, co zdaje się nie mieć zakończenia i wyraża nieskończoną otwartość na inne wymiary bytu i bycia w świecie i w zaświatach. Niebywale prosta budowla złożona z sześcianu i nałożonej nań półkuli nierzadko potrafi wyrazić więcej niż długi wierszowany utwór poetycki lub długa, utrzymana $\mathrm{w}$ prozie, rozprawa filozoficzna.

Właściwie co wyraża architektura? Zwykle mówi się o jej walorach estetycznych lub użytkowych, a przecież architektura zawiera w sobie coś więcej, co dopiero dzięki niej się ujawnia. Nie chodzi tutaj o coś rzeczowego, co wspólne jest wszystkim przedmiotom materialnym, aczkolwiek może słusznie Heidegger stwierdza, że w budowli jest coś kamiennego, co okazuje się w niej tak niezbywalne, że należy zarazem powiedzieć, iż budowla jest w kamieniu ${ }^{21}$. Materiał, z jakiego zbudowano jakiś obiekt architektoniczny, nie jest zatem tylko czymś wtórnym i nieistotnym, ale stanowi podstawę istnienia tego obiektu. Jest on dlań czymś konstytutywnym, co nawet $\mathrm{z}$ ontologicznego punktu widzenia wysuwa się na pierwszy plan, jakby uzależniając od siebie ów obiekt. Gdy zgadzamy się, że zasadne jest mówienie o budowli będącej w kamieniu, to przyznajemy, że kamień jest nie tylko materiałem, z którego zbudowano jakiś obiekt, ale jest też swoistym schronieniem dla niego, jest jego domostwem bycia w świecie i bycia dla nas. W ten sposób rozsadzamy ramy tradycyjnej estetyki, operującej pojęciami materiału (tworzywa) i formy jako odpowiednikami metafizycznych pojęć materii i formy czy uniwersalnych kulturowo pojęć treści i formy. Cóż bowiem jest „źródłem” budowli w kamieniu? Może spontanicznie odpowiemy, że kamień, choć

${ }^{21}$ Martin Heidegger, „Źródło dzieła sztuki”, tłum. Janusz Mizera, w: tenże, Drogi lasu (Warszawa: Fundacja Aletheia, 1997), 9. 
chcielibyśmy raczej powiedzieć, że projekt, wedle którego wzniesiono budowlę, a więc coś idealnego $\mathrm{w}$ porównaniu $\mathrm{z}$ realnością istnienia kamienia.

Aby jeszcze bardziej wyeksponować poziom trudności, z jakimi spotykamy się w estetyce, przywołajmy znany przykład obrazu van Gogha, przedstawiającego parę chłopskich butów. Pomińmy przy tym fakt, że ekscentryczny Holender namalował pięć różnych obrazów nazwanych Para butów, a do tego jeszcze obraz Trzy pary butów, czyli w artystycznym dorobku van Gogha jest aż osiem par butów. Najważniejsza jest tu sama symbolika chłopskich butów, którą odczytuję wedle tego samego klucza co Heidegger, chociaż usiłuję uwzględniać szerszą perspektywę rozumienia istoty wiejskiego obuwia. W swym eseju o źródle dzieła sztuki Heidegger osadza kwestię istnienia wspomnianych butów w kontekście problemu narzędziowości narzędzia. Posługując się jednym z terminów technicznych Heideggera, a więc określeń dobrze wpisujących się w narrację poświęconą rzeczowości sztuki, należałoby powiedzieć, że owe zwykle mocno sfatygowane buciory są dla pracującego na roli chłopa poręcznym narzędziem. Wprawdzie od razu doświadczamy słuchowego dyskomfortu wskutek „zgrzytu” semantycznego, jaki powstaje w chwili, gdy coś, co jest nakładane na nogi, nazywamy czymś poręcznym, czyli czymś pasującym - formalnie - do rąk, a nie do nóg, jednak nie powinniśmy się tym zanadto przejmować. Buty te faktycznie są bowiem jakoś poręczne w znaczeniu użytkowym, albowiem, mając je na nogach, chłop może wygodnie przemieszczać się po świeżo zaoranym polu lub po zabłoconym podwórzu albo swobodnie torować sobie drogę pomiędzy prosiakami przepychającymi się przy żłobie pełnym żarcia. Nie mając ich na nogach, a więc przemieszczając się na bosaka, łatwo mógłby sobie uszkodzić stopy na ostrych kamieniach albo na twardych świńskich tyłkach raczonych kopniakami. Funkcjonalnie rozumiana poręczność butów jako użytecznego narzędzia nie wyczerpuje jednak tematu czegoś więcej, co zawiera się w przedmiocie i - jednocześnie - na co przedmiot wskazuje lub ku czemu nas odsyła. Niewątpliwie Heidegger ma rację, gdy mówiąc o jakiejś rzeczy, zauważa, że nie wystarcza mówienie o samej tej rzeczy: „Sama tylko rzecz jest rodzajem narzędzia, narzędzia jednak pozbawionego swego bycia narzędziem”22. Tak oto dochodzimy do bycia bytu butów, czyli do tego, co jeszcze skrywa się za butami, bez czego buty nie byłyby sobą, gdyż bycie istotnie je dookreśla pod wszystkimi możliwymi względami. Jak wiadomo, różnica ontologiczna między bytem

${ }^{22}$ Tamże, 18. 
a byciem bytu jest osnową całej Heideggerowskiej ontologii fundamentalnej, która, dzięki uwzględnieniu bycia, pretenduje do roli pierwszej ontologii, czyli ontologii poprzedzającej każdą inną ontologię, a nawet metafizykę Arystotelesa, pojmowaną przez wieki jako filozofia pierwsza. Są to niezwykle interesujące zagadnienia, ale lepiej pozostawmy je trochę na uboczu, aby móc od razu skupić się na istocie rzeczy - na istocie tej rzeczy, jaką jest sztuka.

Buty z obrazu van Gogha fascynują nas nie ze względu na nie same. Podobnych butów kiedyś stało bardzo dużo w chłopskich chatach, a jeszcze i dzisiaj niemało ich stoi przy wejściach do przestronnych zabudowań należących do zamożnych gospodarzy. Może i chowają się one po kątach naszych mieszkań i domów, wszak przynajmniej od czasu do czasu warto takie buty nałożyć na nogi i wybrać się gdzieś w strefę pozamiejską, aby poczuć się częścią szeroko pojętej przyrody. Ośmielę się dodać, że oglądając artystyczną wizualizację takowych butów, stworzoną przez van Gogha, również nie zachwycamy się talentem malarskim mistrza. Patrząc na nie, widzimy w nich jeszcze coś, co Heidegger nazwałby byciem butów, a równie dobrze można by określić jakimś innym mianem, o ile tylko uwzględniałoby ono sens istnienia czy wewnętrzną prawdę kogoś, kto te buty nosił. Prawda ma tu zresztą znaczenie nieskrytości (aletheia), o ile dana rzecz faktycznie wykracza ku jakiejś prawdzie. W przypadku butów mówienie o kroczeniu czy wykraczaniu jest chyba jak najbardziej na miejscu. Heidegger powiedziałby: „Ów byt [para chłopskich butów - H.B.] wykracza w nieskrytość swego bycia”23. Wydaje się jednak, że prawda butów jedynie skrywa prawdę użytkownika owych butów, a więc para butów raczej wykracza w nieskrytość bycia chłopa, który z mozołem w nich kroczył, wykonując onegdaj ciężką pracę na roli.

Z obiektem architektonicznym ma się rzecz podobnie jak z parą butów, ponieważ on również wykracza ku jakiejś prawdzie. Jeśli tym obiektem jest świątynia, to bardziej poręcznym narzędziem językowym niż „wykracza” jest słowo „wznosi”. Zatem świątynia ta wznosi się ku nieskrytości bycia osób, które z duchowym mozołem transcendują rzeczywistość, poszukując skrywających się bogów lub skrywającego się Boga. W poezji Hölderlina boskość ma uniwersalny wymiar religijny, dlatego sympatyzujący z poglądami autora elegii Chleb $i$ wino Heidegger nazywa

${ }^{23}$ Tamże, 22. 
Heraklesa, Dionizosa i Chrystusa „jedynymi w trójcy” oraz przyzywa ich na powrót do ludzkiego świata ${ }^{24}$. Niemiecki ontolog fundamentalny posługuje się przykładem greckiej świątyni (chociaż mogłaby to być także chrześcijańska świątynia) i stwierdza, iż budowla ta stoi jawnie, czyli sama nie skrywa i nie odwzorowuje niczego. Wynika stąd jasno, że nie powinniśmy doszukiwać się prawdy świątyni w sobie. Świątynia jest szczególnym rodzajem bytu-dla-nas, albowiem ma ona charakter służebny i jej sensem jest ułatwianie ludziom wznoszenia się ku sakralnemu wymiarowi istnienia. Jak widać, budowla ta wznosi się po to, by gromadzący się w jej murach ludzie mogli wznosić modły ku bogom i oczekiwać od nich odpowiedzi. Tak więc w świątyni otwiera się przed wiernymi sfera święta, a w niej wyistaczają się bogowie. Ujawniająca się za ich sprawą nieskrytość nigdy nie rozpływa się w nieokreśloności, tak jak i sama świątynia nie pozostaje nieokreślona. Mamy tu do czynienia ze skumulowaną określonością, ukształtowaną przez konstytutywnie ludzkie czynniki. Ludzie stają przecież przed bogami nieosłonięci, celowo obnażając się przed nimi i pokazując im albo całą nędzę swego jestestwa, ogrom problemów i trosk, które kształtują ich sponiewieraną egzystencję, albo wielkie szczęście, jakie stało się ich udziałem, ogrom pozytywnych doświadczeń wewnętrznych (duchowych) i zewnętrznych (materialnych), wywołujących niezmierną wdzięczność za otrzymane łaski. Ekstatycznie ujęte człowieczeństwo jest piękne w skrajnych wzlotach i upadkach, w tym, co wywyższa i poniża, co pozwala dotrzeć do pełni bytu i niemal pogrążyć się w niebycie. Heidegger dopowiada: „To właśnie dzieło-świątynia spaja dopiero i skupia zarazem wokół siebie jedność tych kolein i związków, w których narodziny i śmierć, nieszczęście i szczęście, zwycięstwo i klęska, przetrwanie i rozpad przybierają dla istoty ludzkiej postać udzielonego jej losu (Geschick)"25.

Współcześnie rozumiemy już piękno inaczej niż kiedyś, stąd dla nas piękne życie czy choćby piękne chwile w życiu są przeciwieństwem wszelkiego zła, które nas w życiu spotyka. Nie można jednak zapominać o tym, że dla starożytnego Greka prawdziwe piękno wyrażało się prawdziwym cierpieniem. Rozważający złożoną ontologiczno-estetyczną kwestię cierpienia ksiądz Józef Tischner również mówi o patosie egzystencjalnym, który wskazuje „na ból doznawania i sposób przezwyciężania bólu, na bierność i na najbardziej intymną aktywność, na tragedię

\footnotetext{
${ }^{24}$ Heidegger, „Cóż po poecie?”, 217.

${ }^{25}$ Tenże, „Źródło dzieła sztuki”, 27.
} 
upadania i wysiłek pięcia się wzwyż"26, a Nietzsche nawet jest wdzięczny losowi za nękające go nawroty choroby i za wszelkie doznane cierpienia, ponieważ traktuje je jako środki stymulujące samorozwój: „Moje człowieczeństwo jest nieustannym samoprzezwyciężaniem się"27. Obaj myśliciele są zadziwiająco zgodni w swych ocenach, mimo że pierwszy z nich reprezentuje postawę chrześcijańską, a drugi - antychrześcijańską. Warto w tym kontekście wyraźnie powiedzieć, że piękno jakby ogarnia dobro i zło, jednając je ze sobą, lub że - inaczej mówiąc - piękno zawiera się w odpowiednich proporcjach między czynnikami, które odczuwamy jako dobre i złe. Tak więc piękne życie, tak jak piękny obiekt architektoniczny, jest zrównoważone i odpowiednio wymierzone we wszystkich kierunkach.

\section{Zadomowienie w (czaso)przestrzeni architektonicznej}

Do tej pory piękno ukazane zostało na przykładzie budowli religijnych. W nich ujawniło swą ontologiczną złożoność i zależność od jakiegoś bycia absolutnego, które niekoniecznie jest byciem bytu absolutnego. W gruncie rzeczy piękno wiąże się bowiem z nieskrytością człowieka doświadczającego samego siebie w wykraczaniu albo wybieganiu ku czemuś niepojętemu. Dopiero owo niepojęte, na ogół identyfikowane z boskością, pozwala nam pojąć samych siebie. Wszystko to zazwyczaj dzieje się w świątyni, gdzie znajdujemy dogodne warunki do takiego wykraczania ku niepojętemu i wkraczania w samych siebie. Świątynia jest wyróżnionym miejscem na ziemi i nie bez racji we wszystkich czasach przyciągała do siebie zarówno zwyczajnych ludzi, którzy chcieli przebywać w jej wnętrzu, jak i ludzi sztuki, w tym architektów, którzy stale na nowo i na różne sposoby, acz z poszanowaniem ustalonych zasad, koncypowali jej konstrukcję i rozmyślali nad możliwościami jej upiększania. Jednak życie ludzkie nie upływa w tym jednym miejscu, ba, ludzie potrzebują do życia wielu różnych obiektów, rozmieszczonych $\mathrm{w}$ wielu różnych miejscach. Jedne z nich okazjonalnie dają schronienie, inne służą do stałego w nich przebywania. Wszystkie one znajdują się w obszarze zamieszkiwania, mimo że nie wszystkie zapewniają człowiekowi jego własny kąt. Zdaniem Heideggera, specyfiką domu czy mieszkania jest właśnie ten własny kąt, w którym

\footnotetext{
${ }^{26}$ Józef Tischner, Filozofia dramatu (Paris: Éditions du Dialogue, 1990), 70.

${ }^{27}$ Friedrich Nietzsche, Ecce homo, tłum. Bogdan Baran (Kraków: Wydawnictwo Baran i Suszczyński, 1996), 31.
} 
człowiek może znaleźć się naprawdę u siebie. Wydaje się nawet, że ów własny kąt jakby przesłania sobą dom lub mieszkanie. Bez niego można się gdzieś czasowo pomieścić, ale nie można naprawdę mieszkać. Obiekty dające schronienie są niewystarczające: „Człowiek je zamieszkuje, a jednak w nich nie mieszka, skoro «mieszkać» znaczy tylko: posiadać jakiś kąt”28. Jak widać, człowiek ma w swym domu własny kąt, tak jak bóg ma swój własny kąt w świątyni. Jest to piękna konkluzja. Szkoda tylko, że przeprowadzone przez Heideggera analizy językowe, posiłkujące się dawno zapomnianymi określeniami starogermańskimi, nie mają zastosowania w mowie polskiej i przez to tracą nieco na wiarygodności. Szkoda, bo wynika z nich, że być człowiekiem to mieszkać i zarazem otaczać opieką - prawdopodobnie - obszar, w którym się mieszka. Jeżeli opieka nad tym obszarem jest wpisana w istotę człowieczeństwa, to tym bardziej człowiek powinien, w jakimś sensie, identyfikować się z budowlą, w której mieszka. Ona, gwarantując mu własny kąt, jest jego własnością tak samo, jak on sam. Jako tego rodzaju własność, czyli jako coś najbardziej swojskiego, zasługuje na to, by wyglądać pięknie. Skoro ludzie ubierają się także po to, by się stroić, to również ich własne kąty powinni ubierać w rzeczy piękne, tak aby były ładnie ustrojone. Świadczy to nie tylko o nas samych, ale również o naszej kulturze, gdyż z etymologicznego punktu widzenia pojęcia opieki i kultury są sobie niezmiernie bliskie - pewnie tak bliskie, jak człowiek i jego własny kąt, w którym mieszka i naprawdę jest u siebie.

Kontynuując rozważania w duchu Heideggerowskich analiz, dochodzimy do utożsamienia budowania i mieszkania (lub dawania mieszkania). Widać to znowu wyraźniej - paradoksalnie - na przykładzie świątyń, w których, jak sądzimy, mieszkamy nie my, lecz bogowie. W nich bowiem uwidacznia się patos dystansu między nami a bogami, patos szybko zamieniający się w zażyłość. Człowiek jest człowiekiem, o ile mieszka, mając własny kąt, ale to mieszkanie jest tylko doczesne, jako że przebywający na ziemi człowiek jest śmiertelny (u Heideggera owa śmiertelność człowieka nabywa nowej jakości, przez co pisana jest z dużej litery człowiek to Śmiertelny). Bogowie, w odróżnieniu od człowieka, są nieśmiertelni i wiecznie mieszkają gdzieś we własnych kątach oraz w tych kątach, które ludzie im zbudowali (nie wiemy, czy te ostatnie traktują jak własne). Można jednak uznać, po pierwsze, że świątynie, stojąc na ziemi przez wieki, przynajmniej symbolicznie wpisują się w wieczność boskiego istnienia, i że człowiek, wznosząc takie

${ }^{28}$ Heidegger, „Budować, mieszkać, myśleć”, 317. 
budowle, także wznosi się ponad własną śmiertelność i wykracza ku boskiej wieczności. Nie jest wykluczone, że mamy tu do czynienia z antycypacją, czyli z wybiegającym w przyszłość uprzedzeniem tego, co dopiero będzie. Antycypując bycie (z) bogami, ludzie już teraz przyswajają sobie (internalizują) trzy najwyższe idee Platońskie: Dobro, Piękno i Prawdę. Dobrze jest więc budować bogom piękne świątynie, w których człowiek odkrywa prawdę o sobie i odnajduje wieczny (s)pokój ducha. Pojęcie (s)pokoju pojawia się tu nieprzypadkowo, gdyż - według Heideggera - oznacza ono wolną przestrzeń, przestworza. Świątynia, będąc otwarciem ku przestworzom, jest też sprawczynią i dawczynią (s)pokoju, o ile oczywiście mieszkający w niej bogowie doceniają ludzki trud wznoszenia, czyli budowania obiektów religijnych. Wieczny (s)pokój okazuje się być stanem jak najbardziej pożądanym, co wcale nie dziwi, jeśli zważymy, że uwalnianie się od śmiertelności, ze wszystkimi jej negatywnymi skutkami, jest jednocześnie zachowywaniem siebie, najbardziej własną troską o własne, potencjalnie wieczne istnienie. Stale powracają tu określenia śmiertelności (czasowości) ludzi i nieśmiertelności (wieczności) bogów, świata (ziemi) i zaświatów (nieba). To także nie dzieje się przypadkiem: „Wszystkie cztery: Ziemia i Niebo, Istoty Boskie i Śmiertelni mocą jakiejś pierwotnej jedności są jednym"29. Może ta pierwotna jedność powstała za sprawą Plotyńskiej Jedni, a może wzięła się z czegoś zupełnie innego. Tak czy inaczej, przywołuje ona myśl o prawdzie bytu jako byciu tym, co piękne. W średniowieczu dominowało przekonanie, że piękno jest własnością transcendentalną, czyli jest powszechną własnością bytu: „Cokolwiek jest, jest piękne; ens et pulchrum convertuntur. [...] świat jest stworzony przez Boga, więc jakże nie miałby być piękny”30. Nawet jeżeli w twierdzeniu tym jest trochę przesady, to miło jest wiedzieć, że kiedyś piękno odgrywało zasadnicze znaczenie nie tylko w estetyce, ale także w metafizyce.

Heidegger apeluje do nas, byśmy zachowywali czworokąt (das Geviert), złożony z Ziemi i Nieba, Istot Boskich i Śmiertelnych, czyli nas samych. Zamieszkiwanie jest zachowywaniem, dlatego powinniśmy znaleźć nasze własne kąty i czuć się w nich swojsko. Tak oto czynimy już coś więcej dla czworokąta - dajemy wolne pole jego istocie, chronimy jego istotę. Mieszkając, przebywamy przy rzeczach,

${ }^{29}$ Tamże, 321.

${ }^{30}$ Władysław Tatarkiewicz, Historia estetyki, t. 3: Estetyka nowożytna (Wrocław-Kraków: Zakład Narodowy imienia Ossolińskich, 1967), 25. 
które istnieją na wiele sposobów, w tym również na sposób roślin. Głównym zadaniem roślin jest rośnięcie, a naszym - wspieranie tego procesu. Są jednak rzeczy, które rosną tylko $\mathrm{z}$ naszą pomocą. Najlepszym przykładem takich rzeczy są obiekty architektoniczne. Ludzie zachowują czworokąt, gdy „z rozmysłem wznoszą te rzeczy, które nie rosną same"31, tzn. wznoszą budowle na miarę tego czworokąta: „To właśnie od czworokąta budowanie przejmuje miary wszelkiego mierzenia i wymierzania przestrzeni [...]. Budowle przechowują czworokąt. Są to rzeczy, które na swój sposób go zachowują"32. Można słusznie domniemywać, że budowle mają być proporcjonalne, choć niekoniecznie czworokątne. Ich proporcje zależą również od wznoszących je ludzi, czyli od ich własnych proporcji i od proporcji uznanych przez nich za właściwe. Kumulacja tych proporcji powinna zaowocować pięknem „rosnących” budowli, pięknem harmonizującym z pięknem innych rzeczy wypełniających czworokąt.

Spośród wielu możliwych obiektów architektonicznych wznoszonych przez ludzi bardzo ważną funkcję spełniają mosty. W oczach Heideggera są to obiekty, które skupiają wszystko w obrębie czworokąta. Skupienie (Versammlung) jest łączeniem dokonującym się fizycznie i symbolicznie. Zwykle most łączy dwa brzegi rzeki, przez co odnosi je do siebie, tworząc między nimi relację. Nie chodzi jednak tylko o brzegi, ale także o wszystko, co się na tych brzegach znajduje, a nawet co się poza nimi rozciąga. Most łączy wszystko, co znajduje się po jednej stronie, ze wszystkim, co znajduje się po drugiej stronie. Dzięki mostowi rzeczywistość rozdarta rzeką ponownie staje się jednością, która cechuje się bezstronnością. Nieobecność mostu byłaby zarazem nieobecnością związków mogących połączyć różne obszary naszego świata. W rezultacie czworokąt pozbawiony związanych ze sobą elementów składowych nie byłby prawdziwym czworokątem. Heidegger zwraca uwagę na jeszcze jeden aspekt łączenia-spajania. Na naszej drodze życia, już u kresu tej drogi, pojawia się ostatni most, który musimy przejść. Jest to most między Śmiertelnymi a Istotami Boskimi: „Śmiertelni [...], zawsze będąc już $\mathrm{w}$ drodze do ostatniego mostu, dążą w gruncie rzeczy do tego, by przekroczyć to, co zwykłe i spaczone, i doprowadzić się przed niespaczoną boskość" ${ }^{33}$. W mitologii greckiej zwykli śmiertelnicy musieli pokonać rzekę Styks, aby znaleźć się w Hade-

\footnotetext{
${ }^{31}$ Heidegger, „Budować, mieszkać, myśleć”, 323.

${ }^{32}$ Tamże, 331.

${ }^{33}$ Tamże, 325.
} 
sie. Nad Styksem pewnie nie było żadnego mostu, skoro Charon trudnił się transportowaniem ludzi łodzią na drugą stronę rzeki. Chrześcijanom jest łatwiej, ponieważ dzięki symbolicznemu mostowi mogą sami przejść na drugą stronę i znaleźć się w sferze boskości. Jednak, przekraczając most suchą nogą, nie mają okazji, by zanurzyć się w wodzie dającej nieśmiertelność. Może tak jest i lepiej, ponieważ gdyby zrobili to niestarannie i pozostałaby im jakaś nieobmyta „pięta Achillesa”, to de facto powróciliby do stanu śmiertelności, podczas gdy po drugiej stronie mostu mogą liczyć na udział w niekończącej się wieczności. Taka zaś perspektywa niewątpliwie jest piękna.

Nierzadko konstrukcja mostu zasadza się na łuku. Takie rozwiązanie architektoniczne jest statycznie korzystniejsze i dla oka ładniejsze, a jednocześnie daje ono do myślenia. Łuk w powiązaniu z czworokątem od razu kojarzy się bowiem z zarysem projektu świątyni albo innego obiektu użyteczności publicznej, wznoszonego na wieki. Idea budowania, sama z siebie odwieczna, skłania do podejmowania przedsięwzięć mających przetrwać próbę czasu i ostać się w obliczu wieczności. Nawet jeżeli dotąd nie powstał żaden obiekt, o którym można by powiedzieć, że w wymiarze materialnym przejdzie do wieczności, klasyczne formy architektoniczne w wymiarze symbolicznym już stały się ponadczasowe. Podobnie jest $\mathrm{z}$ kwestią przestrzeni $\mathrm{w}$ tychże formach. W wymiarze materialnym mamy tu wprawdzie do czynienia $\mathrm{z}$ przestrzeniami zamkniętymi, ale w wymiarze symbolicznym - jak wiemy - klasyczne formy architektoniczne otwierają przestrzeń ku wyższym poziomom istnienia. Uwznioślając nas i powodując wzlot naszego ducha, wznoszą nas też ku czemuś wyższemu i upragnionemu, dającemu bezgraniczne poczucie spełnienia.

W tym kontekście dość problematyczne wydaje się przedstawione czy tylko przypomniane przez Heideggera rozumienie pojęcia granicy: „Granica nie jest tym, przy czym coś się kończy; dopiero gdy coś jest ograniczone - jak rozpoznali to już Grecy - zaczyna być sobą"34. Trzeba jednak zwrócić baczną uwagę na owo zaczynanie się, aby sobie wyraźnie uzmysłowić, że w przypadku obiektu architektonicznego pojawia się granica, która odsyła do bezgraniczności, a przez to użytkownik takiego obiektu zaczyna stawać się sobą dzięki zamkniętej przestrzeni, ale staje się sobą dopiero po jej symbolicznym ubezgranicznieniu. Zresztą Heidegger

${ }^{34}$ Tamże, 326. 
wyjaśnia, że przestrzeń można rozumieć na dwa sposoby: jest ona spatium, tj. odstępem między poszczególnymi bytami, czy też odległością dzielącą znajdujące się w niej byty, oraz extensio, tj. rozciągłością, czy też czystym rozpostarciem wzwyż, wszerz i wgłąb, które okazuje się już być abstractum, tj. czystą różnorodnością tych trzech wymiarów. Niezwykła atmosfera panująca w klasycznych obiektach architektonicznych powoduje, że ich użytkownik przestaje dostrzegać spatium i niemal zanurza się w extensio, delektując się duchowym pięknem nadprzestrzennej, absolutnej różnorodności: „Przestrzeń przyznana przez tę różnorodność nie jest już jednak określona przez odległości, nie jest już spatium, lecz jest już tylko extensio - rozciągłością" ${ }^{35}$. Z pewną dozą ontologicznej brawury dałoby się powiedzieć, że świadomy użytkownik klasycznego obiektu architektonicznego, jakim jest zwłaszcza świątynia, doświadcza swego rodzaju transsubstancjacji przestrzeni. Podobnie jak podczas Eucharystii chleb i wino zamieniają się w Ciało i Krew Pańską, tak zamknięta przestrzeń budowli (religijnej) zamienia się w otwartą przestrzeń komunikacji z - jak by powiedział Heidegger - Istotami Boskimi.

Zdarzają się sytuacje, gdzie wymiar materialny ustępuje pola wymiarowi symbolicznemu, ale czasem pierwszy z nich jest tak wymowny, że nie wymaga już żadnego dopełnienia, ponieważ sam w sobie jest pełen symboli. Heidegger pisze:

Pomyślmy przez chwilę o jakiejś zagrodzie w Schwarzwaldzie, którą jeszcze przed dwustu laty budowało chłopskie zamieszkiwanie. Dom urządziła tu moc otwierania rzeczy dla prostoty Ziemi i Nieba, Istot Boskich i Śmiertelnych. Postawiła ona zagrodę na osłoniętym od wiatru, południowym zboczu góry, pośród hal, w pobliżu źródła. Dała mu szerokoskrzydły gontowy dach, stosownie ukośny, by mógł udźwignąć ciężary śniegu, nisko opadający, by ochronić izby przed burzami w długie zimowe noce. Nie zapomniała o kącie ze świętymi obrazami nad wspólnym stołem, przyznała w izbach uświęcone miejsce połogowi i «drzewu umarłych» ( Totenbaum) - tak w tamtych stronach nazywają trumnę - i w ten sposób różnym porom życia wytyczyła pod jednym dachem tor ich wędrówki przez czas. Zagrodę tę zbudowało rękodzieło, które samo miało źródło w zamieszkiwaniu i używa jeszcze swych narzędzi i przyborów jako rzeczy ${ }^{36}$.

\footnotetext{
${ }^{35}$ Tamże, 327-328.

${ }^{36}$ Tamże, 333.
} 
Oczywiście Heidegger nie zachęca do stawiania dzisiaj takich domostw, chociaż trzeba przyznać, że dobrze wyglądałyby przy nich buty z obrazu van Gogha. Z artystycznego punktu widzenia oba motywy doskonale się z sobą komponują, urzekając nas swym rustykalnym pięknem. Urzeka nas także sposób myślenia i mówienia filozofa o duchowych klimatach architektury jako sztuki budowania. Jest to nie tylko myślenie inspirujące do zamieszkiwania i zadomawiania się w bycie, ale także myślenie, które samo jest strzeżonym przez myślicieli domem bycia (Haus des Seins) oraz domostwem istoty człowieka (Behausung des Menschenwesens). Wypada tu jeszcze raz dopuścić do głosu Heideggera:

\begin{abstract}
Myślenie pracuje przy budowie domu bycia. Dom ten to mieszkanie w prawdzie bycia każdorazowo udzielane istocie człowieka przez spojenie bycia. Zamieszkiwanie w prawdzie bycia stanowi istotę «bycia-w-świecie» [...]. Mówienie o domostwie bycia nie jest przeniesieniem obrazu «domu» na bycie. To raczej dzięki odpowiednio pomyślanej istocie bycia zdołamy któregoś dnia myśleć to, czym jest «dom» i co znaczy «mieszkać» ${ }^{37}$.
\end{abstract}

Te piękne słowa skłaniają ku głębokiemu namysłowi nad rolą architektury w życiu człowieka, a zarazem potwierdzają aktualność greckiego przekonania o pokrewieństwie zmysłowego wrażenia (estetycznego) i intelektualnego namysłu nad (nie tylko) pięknymi rzeczami tego świata. Jak bowiem zauważa Tatarkiewicz, „Grecy posługiwali się wyrazem aisthesis oznaczającym wrażenie zmysłowe i występującym w parze z wyrazem noesis, oznaczającym myślenie"38. Estetyka, w tym również estetyka architektoniczna, zasadza się współzależności odczuwania i myślenia albo - inaczej mówiąc - tego, co zmysłowe i tego, co racjonalne.

\title{
Wyprowadzenie ku absolutności bycia sztuki budowania
}

Niezależnie od tego, czy myślimy o świątyni greckiej lub chrześcijańskiej, czy o prostej chacie chłopskiej, czy o pozostałych rodzajach obiektów architektonicznych, jak choćby o mostach, powinniśmy tak myśleć, aby myślenie to było już bu-

${ }^{37}$ Martin Heidegger, „List o «humanizmie»”, tłum. Józef Tischner, w: tenże, Znaki drogi (Warszawa: Fundacja Aletheia, 1995), 164.

${ }^{38}$ Władysław Tatarkiewicz, Dzieje sześciu pojęć. Sztuka, piękno, forma, twórczość, odtwórczość przeżycie estetyczne (Warszawa: PWN, 1988), 362. 
dowaniem - przynajmniej budowaniem teoretycznych podwalin takiej współczesnej teorii budowania, która respektuje Witruwiańskie reguły i w praktyce pozwala nam otaczać się pięknymi rzeczami oraz duchowo wzrastać w pięknie, napawając się nieogarnioną wzniosłością. Niech to będzie myślenie zbierające mowę w prostą opowieść o architekturze i pozostawiające tą opowieścią niepozorne bruzdy w mowie, które są ,jeszcze bardziej niepozorne od tych, jakie wieśniak wolnym krokiem żłobi na polu"39 , być może krocząc w butach uwiecznionych przez van Gogha i powoli wykraczając w nich w nieskrytość ostatniego własnego kąta, znajdującego się w jednym spośród wielu mieszkań w domu Ojca ${ }^{40}$.

\section{Bibliografia}

Augustyn św. „O porząadku”. Tłum. Józef Modrzejewski. W: św. Augustyn. Dialogi filozoficzne. Kraków: Znak, 2001.

Augustyn św. Państwo Boże. Tłum. Władysław Kubicki. Kęty: Wydawnictwo Antyk, 2002.

Biblia Tysiąclecia. Poznań-Warszawa: Pallotinum, 1982.

Heidegger, Martin. „Budować, mieszkać, myśleć”. Tłum. Krzysztof Michalski. W: Martin Heidegger. Budować, mieszkać, myśleć. Warszawa: Czytelnik, 1977.

Heidegger, Martin. „Cóż po poecie?”. Tłum. Krzysztof Wolicki. W: Martin Heidegger, Drogi lasu. Warszawa: Fundacja Aletheia, 1997.

Heidegger, Martin. „List o «humanizmie»”. Tłum. Józef Tischner. W: Martin Heidegger, Znaki drogi. Warszawa: Fundacja Aletheia, 1995.

Heidegger, Martin. „Źródło dzieła sztuki”. Tłum. Janusz Mizera. W: Martin Heidegger, Drogi lasu. Warszawa: Fundacja Aletheia, 1997.

Kant, Immanuel. Krytyka władzy sądzenia. Tłum. Jerzy Gałecki. Warszawa: PWN, 2004.

Nietzsche, Friedrich. Ecce homo. Tłum. Bogdan Baran. Kraków: Wydawnictwo Baran i Suszczyński, 1996.

Nietzsche, Friedrich. Narodziny tragedii albo Grecy i pesymizm. Tłum. Bogdan Baran. Kraków: Wydawnictwo Baran i Suszczyński, 2001.

Platon. „Uczta”. Tłum. Władysław Witwicki. W: Platon, Uczta. Eutyfron. Obrona Sokratesa. Kriton. Fedon. Warszawa: PWN, 1982.

Tatarkiewicz, Władysław. Dzieje sześciu pojęć. Sztuka, piękno, forma, twórczość, odtwórczość, przeżycie estetyczne. Warszawa: PWN, 1988.

Tatarkiewicz, Władysław. Historia estetyki, T. 1: Estetyka starożytna. Wrocław-Kraków: Zakład Narodowy imienia Ossolińskich, 1960.

\footnotetext{
${ }^{39}$ Heidegger, „List o «humanizmie»”, 168.

${ }^{40}$ Zob. J 14, 2.
} 
Tatarkiewicz, Władysław. Historia estetyki, T. 2: Estetyka średniowieczna. Wrocław-Kraków: Zakład Narodowy imienia Ossolińskich, 1960.

Tatarkiewicz, Władysław. Historia estetyki, T. 3: Estetyka nowożytna. Wrocław-Kraków: Zakład Narodowy imienia Ossolińskich, 1967.

Tischner, Józef. Filozofia dramatu. Paris: Éditions du Dialogue, 1990.

Tomasz św. Suma teologiczna, T. 1: O Bogu. Tłum. o. Pius Bełch OP. Londyn: Katolicki Ośrodek Wydawniczy „Veritas”, 1975.

Witruwiusz. O architekturze ksiąg dziesięć. Tłum. Kazimierz Kumaniecki. Warszawa: PWN, 1956.

\section{Summary}

\section{The ontology of the beautiful and the sublime in architecture.}

\section{Heideggerian inspirations}

According to the Greek approach to art as techne, architecture is the art of construction and is subject to the established rules of art creation. The idea of beauty, however, exceeds the rigid frame of the canon since kalón not only has an aesthetic character, but also an ethical and religious one. Religious buildings are open to the world and other people (the horizontal dimension) and to the afterworld and gods or God (the vertical dimension). The fundamental ontology of Heidegger guides us to the true nature of beauty, one which renews relationships between earth and sky, between divinities and mortals. It teaches us that building, dwelling and thinking share the same source. When designing, it is necessary not only to keep measure and proportions in mind in order to meet the need for beauty and usability, but also to take into account these relationships. In this way, the house of being and the home of man's essence are protected.

Keywords: architecture, beautiful, sublime, canon, ontology, Heidegger

\section{Zusammenfassung}

\section{Die Ontologie des Schönen und des Erhabenen in der Architektur. Heideggerianische Inspirationen}

Nach der griechischen Auffassung von Kunst als Technik (techne) ist Architektur eine Baukunst, die festen Regeln des Kunstschaffens unterliegt. Die Idee der Schönheit geht jedoch über einen starren Rahmen des Kanons hinaus, da kalón nicht nur einen ästhetischen, sondern 
auch einen ethischen und religiösen Charakter hat. Religiöse Objekte sind offen für die Welt und andere Menschen (horizontale Dimension) und für das Jenseits und Götter oder Gott (vertikale Dimension). Die Fundamentalontologie von Heidegger führt uns zur wahren Natur der Schönheit, die die Beziehungen zwischen Erde und Himmel, zwischen den Göttlichen und Sterblichen erneuert. Sie lehrt uns, dass Bauen, Wohnen und Denken im Wesentlichen die gleiche Quelle haben. Um dem Bedürfnis nach Schönheit und Benutzerfreundlichkeit gerecht zu werden, müssen beim Entwerfen nicht nur Maße und Proportionen, sondern auch diese Beziehungen berücksichtigt werden. Auf diese Weise werden das Haus des Seins und die Behausung des Menschenwesens gehütet.

Schlüsselworte: Architektur, Schöne, Erhabene, Kanon, Ontologie, Heidegger

Information about Author:

HENRYK BENISZ, professor, PhD, DSc, Faculty of Social Sciences, University of Opole; address for correspondence: Wydział Nauk Społecznych Uniwersytetu Opolskiego, ul. Oleska 48, PL 45-052 Opole; e-mail: benisz@uni.opole.pl 